\title{
Cytokines, inducers and inhibitors modulate MMP-2 and MMP-9 secretion by human Fanconi anemia immortalized fibroblasts
}

\author{
M.W. ROOMI, T. KALINOVSKY, M. RATH and A. NIEDZWIECKI \\ Dr. Rath Research Institute, Santa Clara, CA 95050, USA
}

Received July 1, 2016; Accepted August 16, 2016

DOI: $10.3892 /$ or.2017.5368

\begin{abstract}
Acute myeloid leukemia and head and neck squamous cell carcinomas are the major causes of mortality and morbidity in Fanconi anemia (FA) patients. Matrix metalloproteinases (MMPs), particularly MMP-2 and MMP-9, have been implicated in tumor invasion and metastasis. Various cytokines, mitogens, growth factors, inducers and inhibitors control MMP activities. We investigated the roles of these in the regulation of MMP-2 and MMP-9 in human immortalized fibroblasts from FA. Human FA immortalized fibroblast cell lines FA-A:PD220 and FA-D2:PD20 were grown in minimum essential medium (MEM) supplemented with $15 \%$ fetal bovine serum (FBS) and antibiotics in 24-well tissue culture plates. At near confluence, the cells were washed with phosphate-buffered saline (PBS) and incubated in serum-free media with the following: phorbol 12-myristate 13-acetate (PMA) at $10-100 \mathrm{ng} / \mathrm{ml}$; tumor necrosis factor- $\alpha$ (TNF- $\alpha$ ) and interleukin-1 $\beta$ (IL-1 $\beta$ ) at $0.1-25 \mathrm{ng} / \mathrm{ml}$; lipopolysaccharide (LPS) at $10-100 \mu \mathrm{g} / \mathrm{ml}$; epigallocatechin gallate (EGCG) and doxycycline (Dox) at 10-100 $\mu \mathrm{M}$ without and with PMA; a nutrient mixture (NM) without and with PMA at 10-1,000 $\mu \mathrm{g}$ / $\mathrm{ml}$; actinomycin-D and cyclohexamide at 2 and $4 \mu \mathrm{M}$; retinoic acid and dexamethasone at $50 \mu \mathrm{M}$. After $24 \mathrm{~h}$, media were removed and analyzed for MMP-2 and MMP-9 by zymography. Both FA cell lines expressed only MMP-2 and responded similarly to cytokines, mitogens, inducers and inhibitors. PMA potently stimulated MMP-9 and had a moderate effect on MMP-2. TNF- $\alpha$ showed variable effects on MMP-2 and significantly enhanced MMP-9. IL-1 $\beta$ enhanced MMP-2 slightly and MMP-9 significantly. LPS had a moderate stimulatory effect on MMP-2 and no effect on MMP-9. EGCG, Dox and NM, without and with PMA, downregulated MMP-2 and MMP-9 expression. Actinomycin-D, retinoic acid and dexamethasone also had inhibitory effects on MMP-2. Our results showed that cytokines, mitogens and inhibitors modulated
\end{abstract}

Correspondence to: Dr Aleksandra Niedzwiecki, Dr. Rath Research Institute, 1260 Memorex Drive, Santa Clara, CA 95050, USA

E-mail: author@drrath.com

Key words: matrix metalloproteinases, Fanconi anemia fibroblasts, cytokines, inducers, inhibitors
FA fibroblast MMP-2 and MMP-9 expression, suggesting the clinical use of MMP inhibitors, particularly such potent and non-toxic ones as the NM and its component EGCG in the management of FA cancers.

\section{Introduction}

Fanconi anemia (FA) is a heterogeneous autosomal recessive disease characterized by congenital malformations, progressive bone marrow failure and an increased incidence of cancer. In contrast to normal fibroblasts, FA fibroblasts display elevated spontaneous chromosomal breaks and deletions and nuclear extracts that have substantially decreased plasmid-rejoining activity $(1,2)$. Epanchintsev et al demonstrated the overproduction of secretory factors such as interleukin (IL)-6, IL-8, matrix metalloproteinase (MMP)-2, and MMP-9 in FA and showed that these overexpressed secretory factors were effective in promoting the proliferation, migration and invasion of surrounding tumor cells (3). Ibáňez et al described an anomalous high level of the pro-inflammatory cytokine IL-1 $\beta$ present in the serum of FA patients which activated the proliferation of tumor cells (4). Increased levels of MMP-9 have been shown to be associated with cancer progression and poorer patient prognosis due to the significant role MMP-9 plays in tumor cell invasion and metastasis by digesting the basement membrane and components of the extracellular matrix (5-7). MMP activity is regulated by and dependent upon environmental influences from surrounding stroma cells, ECM proteins, systemic hormones and other factors $(5,8,9)$. Furthermore, MMPs are regulated at multiple levels, including transcription, modulation of messenger RNA half-life (translation), secretion, localization, activation and inhibition (10).

In the present study we investigated the effects of selected cytokines, inducers and inhibitors affecting cancer cell metabolism on the regulation of MMP-2 and MMP-9 activities in FA fibroblast cell lines.

\section{Materials and methods}

Materials. Human FA fibroblast cell lines A:PD20 and A:PD220 were obtained from the Fanconi Anemia Research Fund, Oregon Health \& Science University (Portland, OR, USA). Antibiotics, penicillin and fetal bovine serum (FBS), were obtained from Gibco-BRL (Long Island, NY, USA). Twenty-four well tissue culture plates were obtained from 
Costar (Cambridge, MA, USA). Gelatinase zymography was performed on $10 \%$ Novex pre-cast SDS polyacrylamide gel (Invitrogen Inc., Carlsbad, CA, USA) with $0.1 \%$ gelatin in non-reducing conditions. IL- $1 \beta$, tumor necrosis factor- $\alpha$ (TNF$\alpha$ ), phorbol 12-myristate 13-acetate (PMA), lipopolysaccharide (LPS), doxycycline, epigallocatechin gallate (EGCG), actinomycin-D, cyclohexamide, retinoic acid and dexamethasone were purchased from Sigma-Aldrich (St. Louis, MO, USA). The nutrient mixture (NM), prepared by VitaTech (Hayward, CA, USA) was composed of the following ingredients in the relative amounts indicated: vitamin $\mathrm{C}$ (as ascorbic acid and as $\mathrm{Mg}, \mathrm{Ca}$ and palmitate ascorbate) $700 \mathrm{mg}$; L-lysine $1,000 \mathrm{mg}$; L-proline $750 \mathrm{mg}$; L-arginine $500 \mathrm{mg}$; $\mathrm{N}$-acetyl cysteine $200 \mathrm{mg}$; standardized green tea extract ( $80 \%$ polyphenol) 1,000 mg; selenium $30 \mu \mathrm{g}$; copper $2 \mathrm{mg}$; manganese $1 \mathrm{mg}$. All other reagents used were of high quality and were obtained from Sigma-Aldrich, unless otherwise indicated.

Cell cultures. FA fibroblasts were grown in Dulbecco's modified Eagle's medium (DMEM), supplemented with 15\% FBS, $100 \mathrm{U} / \mathrm{ml}$ penicillin and $100 \mu \mathrm{g} / \mathrm{ml}$ streptomycin in 24-well tissue culture plates. The cells were plated at a density of $1 \times 10^{5}$ cells $/ \mathrm{ml}$ and grown to confluency in a humidified atmosphere of $5 \% \mathrm{CO}_{2}$ at $37^{\circ} \mathrm{C}$. Serum-supplemented media were removed and the cell monolayer was washed once with phosphate-buffered saline (PBS) and with the recommended serum-free media. The cells were then incubated in $0.5 \mathrm{ml}$ of serum-free medium with various cytokines, mitogens, inducers and inhibitors in triplicates, as indicated: PMA $(10,25,50$ and $100 \mathrm{ng} / \mathrm{ml})$; TNF- $\alpha(0.1,1,10$ and $25 \mathrm{ng} / \mathrm{ml}) ; \operatorname{IL}-1 \beta(0.1,1$, 10 and $25 \mathrm{ng} / \mathrm{ml}) ; \operatorname{LPS}(10,25,50$ and $100 \mu \mathrm{g} / \mathrm{ml}) ; \mathrm{EGCG}$ $(10,25,50$ and $100 \mu \mathrm{M})$ without and with PMA $100 \mathrm{ng} / \mathrm{ml}$; doxycycline $(10,25,50$ and $100 \mu \mathrm{M})$ without and with PMA $100 \mathrm{ng} / \mathrm{ml}$; NM (10, 50, 100, 500 and 1,000 $\mu \mathrm{g} / \mathrm{ml})$ with PMA $100 \mathrm{ng} / \mathrm{ml}$, retinoic acid $(50 \mu \mathrm{M})$; dexamethasone $(50 \mu \mathrm{M})$; actinomycin-D and cyclohexamide ( 2 and $4 \mu \mathrm{g} / \mathrm{ml})$. The plates were then returned to the incubator. The conditioned medium from each treatment was separately collected, pooled and centrifuged at $4^{\circ} \mathrm{C}$ for $10 \mathrm{~min}$ at $3,000 \mathrm{rpm}$ to remove cells and cell debris. The clear supernatant was collected and used for gelatinase zymography as described below.

Gelatinase zymography. Gelatinase zymography was utilized due to its high sensitivity to gelatinolytic enzymatic activity and ability to detect both pro- and active forms of MMP-2 and MMP-9. Upon renaturation of the enzyme, the gelatinases digest the gelatin in the gel and reveal clear bands against an intensely stained background. Gelatinase zymography was performed on $10 \%$ Novex pre-cast SDS polyacrylamide gel in the presence of $0.1 \%$ gelatin under non-reducing conditions. Culture media $(20 \mu \mathrm{l})$ were mixed with sample buffer and loaded for SDS-PAGE with Tris-glycine-SDS buffer, as suggested by the manufacturer (Novex). Samples were not boiled before electrophoresis. Following electrophoresis the gels were washed twice in $2.5 \%$ Triton X-100 for 30 min at room temperature to remove SDS. The gels were then incubated at $37^{\circ} \mathrm{C}$ overnight in a substrate buffer containing $50 \mathrm{mM}$ Tris- $\mathrm{HCl}$ and $10 \mathrm{mM} \mathrm{CaCl}$ at $\mathrm{pH} 8.0$ and stained with $0.5 \%$ Coomassie Blue R250 in 50\% methanol and $10 \%$ glacial acetic acid for $30 \mathrm{~min}$ and destained. Protein
Table I. Effect of inducers on Fanconi anemia fibroblast MMP-2 and MMP-9 secretion.

\begin{tabular}{|c|c|c|}
\hline Inducers & MMP-2 (\%) & MMP-9 (\%) \\
\hline \multicolumn{3}{|c|}{ PMA (ng/ml) } \\
\hline Control & 100 & 0 \\
\hline 10 & 126 & 16.5 \\
\hline 25 & 217 & 33.5 \\
\hline 50 & 236 & 32 \\
\hline 100 & 167 & 19 \\
\hline \multicolumn{3}{|c|}{ TNF- $\alpha(\mathrm{ng} / \mathrm{ml})$} \\
\hline Control & 100 & 100 \\
\hline 0.1 & 156 & 365 \\
\hline 1 & 140 & 622 \\
\hline 10 & 90 & 5,660 \\
\hline 25 & 92 & 6,487 \\
\hline \multicolumn{3}{|c|}{$\mathrm{IL}-1 \beta(\mathrm{ng} / \mathrm{ml})$} \\
\hline Control & 100 & 100 \\
\hline 0.1 & 82 & 145 \\
\hline 1 & 121 & 880 \\
\hline 10 & 173 & 1,216 \\
\hline 25 & 111 & 700 \\
\hline \multicolumn{3}{|c|}{ LPS $(\mu \mathrm{g} / \mathrm{ml})$} \\
\hline Control & 100 & \\
\hline 10 & 118 & \\
\hline 25 & 170 & \\
\hline 50 & 104 & \\
\hline 100 & 65 & \\
\hline
\end{tabular}

MMPs, matrix metalloproteinases; PMA, phorbol 12-myristate 13 -acetate; TNF- $\alpha$, tumor necrosis factor- $\alpha$; IL- $1 \beta$, interleukin-1 $\beta$; LPS, lipopolysaccharide.

standards were run concurrently and approximate molecular weights were determined by plotting the relative mobilities of known proteins. Gelatinase zymograms were scanned using CanoScan 9950F Canon scanner at 300 dpi. The intensity of the bands was evaluated using the pixel-based densitometer program Un-Scan-It, version 5.1, 32-bit, by Silk Scientific Corporation (Orem, UT, USA), at a resolution of 1 scanner unit (1/100 of an inch for an image that was scanned at $100 \mathrm{dpi})$.

\section{Results}

Inducers and cytokines. Both FA cell lines A:PD20 and A:PD220 expressed only one band corresponding to MMP-2. Cytokines, mitogens, inducers and inhibitors had a similar effect on MMP-2 and PMA-induced MMP-9 expression in both FA fibroblasts. Therefore, only data for FA A:PD20 is presented. Table I shows the quantitative densitometry results from the effects of PMA, TNF- $\alpha$, IL-1 $\beta$ and LPS on MMP-2 and MMP-9 expression in the FA fibroblasts.

Effect of PMA on FA fibroblast secretion of MMPs. Upon gelatinase zymography, FA fibroblasts demonstrated moderate 

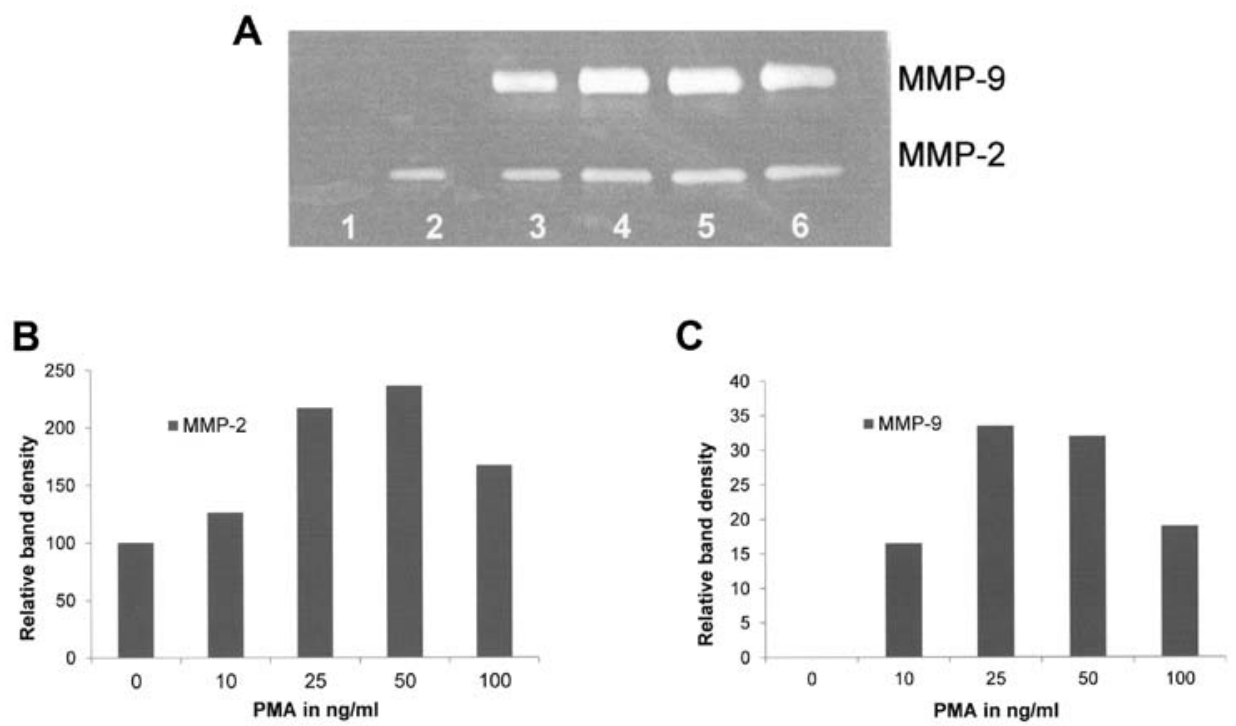

Figure 1. Effect of PMA on MMP-2 and MMP-9 expression in the FA-A:PD20 cell line. (A) Gelatinase zymogram of MMP-2 and MMP-9. Densitometry analysis of FA fibroblast (B) MMP-2 and (C) MMP-9 expression levels. Lane 1, markers; lane 2, control; lanes 3-6: 10, 25, 50, $100 \mathrm{ng} / \mathrm{ml}$ of PMA, respectively. PMA, phorbol 12-myristate 13-acetate; MMP, matrix metalloproteinase; FA, Fanconi anemia.
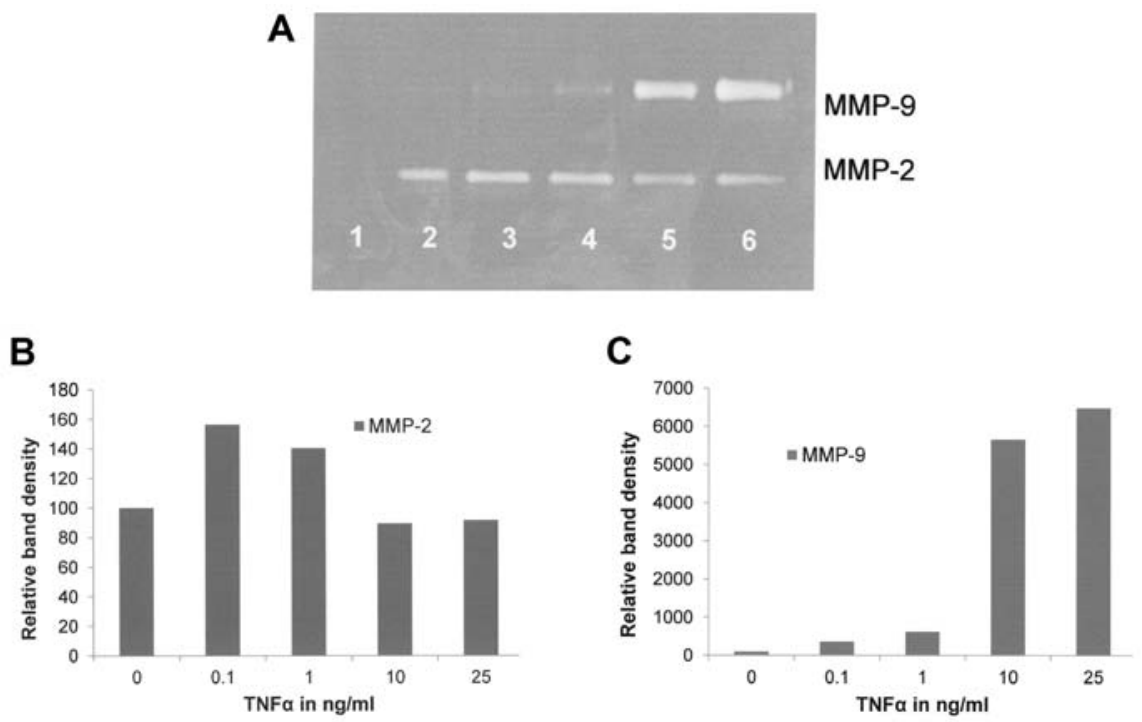

Figure 2. Effect of TNF $\alpha$ on MMP-2 and MMP-9 secretion in the FA-A:PD20 cell line. (A) Gelatinase zymogram of MMP-2 and MMP-9 secretion. Densitometry analysis of FA fibroblast (B) MMP-2 and (C) MMP-9 expression levels. Lane 1, markers; lane 2, control; lanes 3-6: 0.1, 1, 10 and 25 ng/ml of TNF $\alpha$, respectively. TNF- $\alpha$, tumor necrosis factor- $\alpha$; MMP, matrix metalloproteinase; FA, Fanconi anemia.

expression of MMP-2 and no expression of MMP-9. PMA treatment had a moderate stimulatory effect on the expression of MMP-2 (linear trend $\mathrm{R}^{2}=0.4446$ ) and strongly stimulated MMP-9 expression in a dose-dependent manner (linear trend $\mathrm{R}^{2}=0.4084$ ) as shown in Fig. 1 .

Effect of TNF $\alpha$ on FA fibroblast secretion of MMPs. TNF- $\alpha$ had a negligible effect on MMP-2 $\left(\mathrm{R}^{2}=0.1844\right)$ and a significant stimulatory dose-dependent effect on MMP-9 $\left(R^{2}=0.824\right)$ as shown in Fig. 2.

Effect of IL-1 $\beta$ on FA fibroblast secretion of MMPs. IL-1 $\beta$ caused slight stimulation of MMP-2 at 1 and $10 \mathrm{ng} / \mathrm{ml}$ $\left(R^{2}=0.273\right)$, and had significant stimulatory dose-dependent effects on MMP-9 $\left(\mathrm{R}^{2}=0.558\right)$ as shown in Fig. 3.
Effect of LPS on FA fibroblast secretion of MMPs. LPS had a moderate stimulatory effect on MMP-2 secretion below $50 \mu \mathrm{g} / \mathrm{ml}$ and an inhibitory effect at 50 and $100 \mu \mathrm{g} / \mathrm{ml}$ (Fig. 4) and no effect on MMP-9 (data not shown).

Chemical inhibitors. Table II shows the quantitative densitometry results from the effects of the chemical inhibitors doxycycline, dexamethasone and actinomycin-D on MMP-2 and MMP-9 expression in FA fibroblast cell lines.

Doxycycline showed increased FA fibroblast MMP-2 secretion at 10 and $25 \mu \mathrm{M}$, and decreased secretion at 50 and $100 \mu \mathrm{M}$ with virtual total blockage at $100 \mu \mathrm{M}\left(\mathrm{R}^{2}=0.296\right)$. When treated with PMA $100 \mathrm{ng} / \mathrm{ml}$, doxycycline downregulated the expression of FA fibroblast MMP-2 and MMP-9 in a dose-dependent manner, with virtual total blockage of 

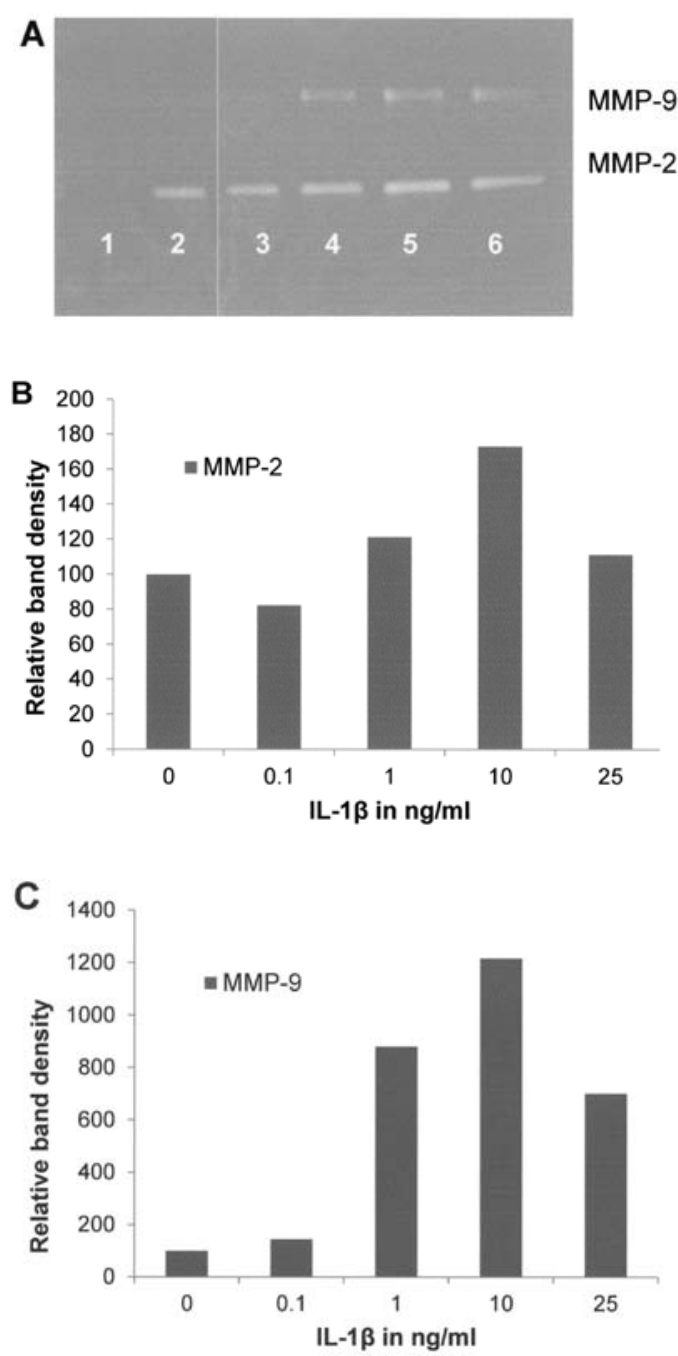

Figure 3. Effect of IL-1 $\beta$ on MMP-2 and MMP-9 secretion in the FA-A:PD20 cell line. (A) Gelatinase zymogram of MMP-2 and MMP-9 secretion. Densitometry analysis of FA fibroblast (B) MMP-2 and (C) MMP-9 expression levels. Lane 1, markers; lane 2, control; lanes 3-6: 0.1, 1, 10 and $25 \mathrm{ng} / \mathrm{ml}$ of IL-1 $\beta$, respectively. IL-1 $\beta$, interleukin-1 $\beta$; MMP, matrix metalloproteinase; FA, Fanconi anemia.
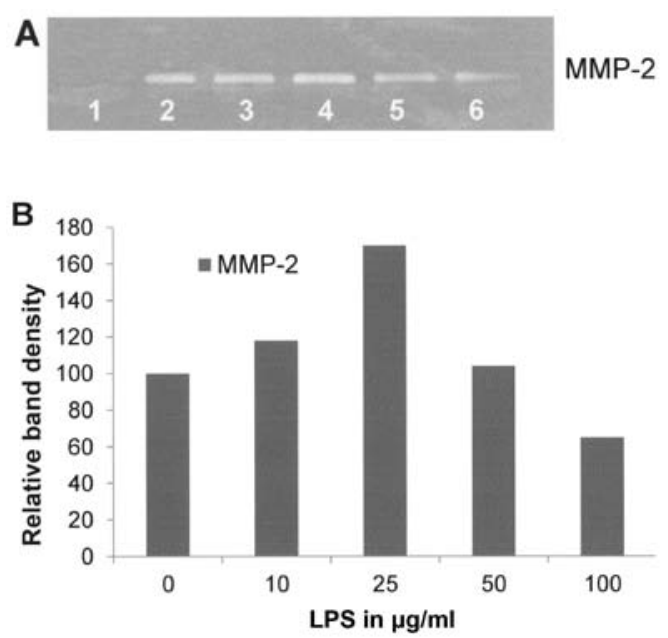

Figure 4. Effect of LPS on MMP-2 secretion in the FA-A:PD20 cell line. (A) Gelatinase zymogram and (B) densitometry analysis of FA fibroblast MMP-2. Lane 1, markers; lane 2, control; lanes 3-6: 10, 25, 50 and $100 \mu \mathrm{g} / \mathrm{m}$ of LPS, respectively. LPS, lipopolysaccharide; MMP, matrix metalloproteinase; FA, Fanconi anemia.
Table II. Effect of inhibitors on Fanconi anemia fibroblast MMP-2 and MMP-9 secretion.

\begin{tabular}{|c|c|c|c|}
\hline \multirow[b]{2}{*}{ Inhibitors } & \multirow{2}{*}{$\frac{\text { Untreated }}{\text { MMP-2 }}$} & \multicolumn{2}{|c|}{$\begin{array}{l}\text { PMA-treated } \\
(100 \mathrm{ng} / \mathrm{ml})\end{array}$} \\
\hline & & $\begin{array}{c}\text { MMP-2 } \\
(\%)\end{array}$ & $\begin{array}{c}\text { MMP-9 } \\
(\%)\end{array}$ \\
\hline \multicolumn{4}{|c|}{ Doxycycline $(\mu \mathrm{M})$} \\
\hline Control & 100 & 100 & 100 \\
\hline 10 & 265 & 59 & 4 \\
\hline 25 & 255 & 55 & 7 \\
\hline 50 & 49 & 8 & 0.5 \\
\hline 100 & 1 & 0.5 & 0.5 \\
\hline \multicolumn{4}{|c|}{ EGCG $(\mu \mathrm{M})$} \\
\hline Control & 100 & 100 & 100 \\
\hline 10 & 201 & 118 & 16 \\
\hline 25 & 148 & 107 & 13 \\
\hline 50 & 75 & 39 & 1 \\
\hline 100 & 17 & 0.5 & 0.5 \\
\hline \multicolumn{4}{|c|}{$\mathrm{NM}(\mu \mathrm{g} / \mathrm{ml})$} \\
\hline Controls & 100 & 100 & 100 \\
\hline 10 & 112 & 98 & 53 \\
\hline 50 & 80 & 102 & 30 \\
\hline 100 & 19 & 49 & 10 \\
\hline 500 & 1 & 1 & 1 \\
\hline 1,000 & 1 & 1 & 1 \\
\hline \multicolumn{4}{|c|}{ Dexamethasone $(\mu \mathrm{M})$} \\
\hline Control & 100 & & \\
\hline 50 & 12 & & \\
\hline \multicolumn{4}{|c|}{ Retinoic acid $(\mu \mathrm{M})$} \\
\hline Control & 100 & & \\
\hline 50 & 7 & & \\
\hline \multicolumn{4}{|c|}{ Actinomycin-D $(\mu \mathrm{M})$} \\
\hline Control & 100 & & \\
\hline 2 & 56 & & \\
\hline 4 & 67 & & \\
\hline
\end{tabular}

MMPs, matrix metalloproteinases; EGCG, epigallocatechin gallate; $\mathrm{NM}$, nutrient mixture.

MMP-2 at $100 \mu \mathrm{M}\left(\mathrm{R}^{2}=0.9378\right)$ and of MMP-9 at $50 \mu \mathrm{M}$ $\left(\mathrm{R}^{2}=0.5403\right)$ as shown in Fig. 5. Actinomycin-D had a slight inhibitory effect on MMP-2 $\left(\mathrm{R}^{2}=0.5355\right)$ with $33 \%$ inhibition at $4 \mu \mathrm{M}$ as shown in Fig. 6. Dexamethasone had a potent inhibitory effect on MMP-2, with inhibition of $88 \%$ at $50 \mu \mathrm{M}$ compared to the control (data not shown). Cyclohexamide had no effect on MMP-2 secretion by FA fibroblasts (data not shown).

Natural inhibitors. Table II shows the quantitative densitometry results from the effects of natural inhibitors EGCG, NM and retinoic acid on MMP-2 and MMP-9 expression in FA fibroblast cell lines. 
A

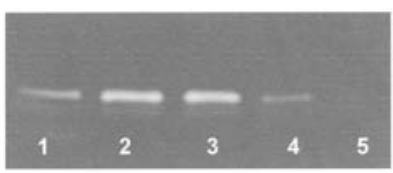

C

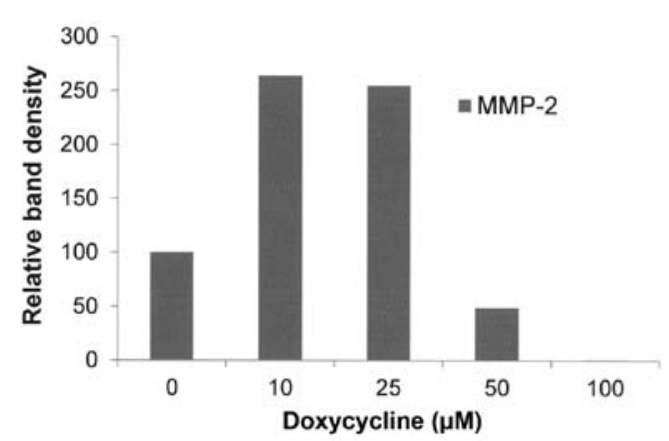

B

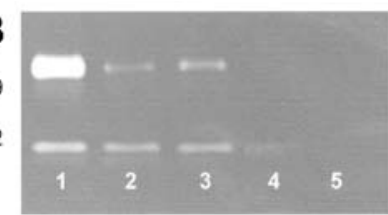

D

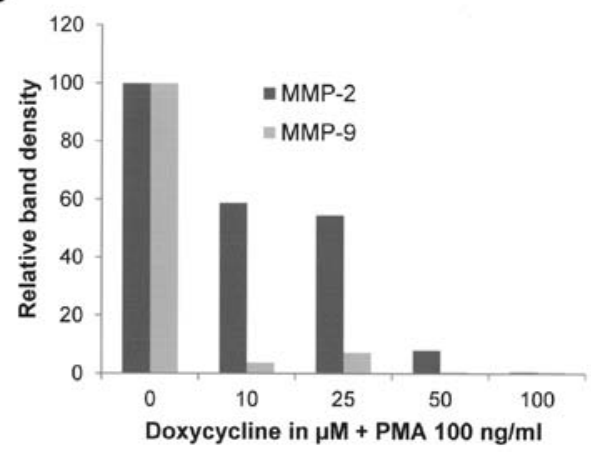

Figure 5. Effect of doxycycline on MMP-2 and MMP-9 secretion of normal and PMA-treated (100 ng/ml) FA-A:PD20 cells. (A) Gelatinase zymograms of normal FA fibroblast cells. (B) PMA-treated FA fibroblast cells. (C) Densitometry analysis of normal FA fibroblast cells and (D) PMA-treated FA fibroblast cells. Lane 1, markers; lane 2, control; lanes 2-5, 10, 25, 50 and $100 \mu \mathrm{M}$ of doxycycline, respectively. PMA, phorbol 12-myristate 13-acetate; MMP, matrix metalloproteinase; FA, Fanconi anemia.

A
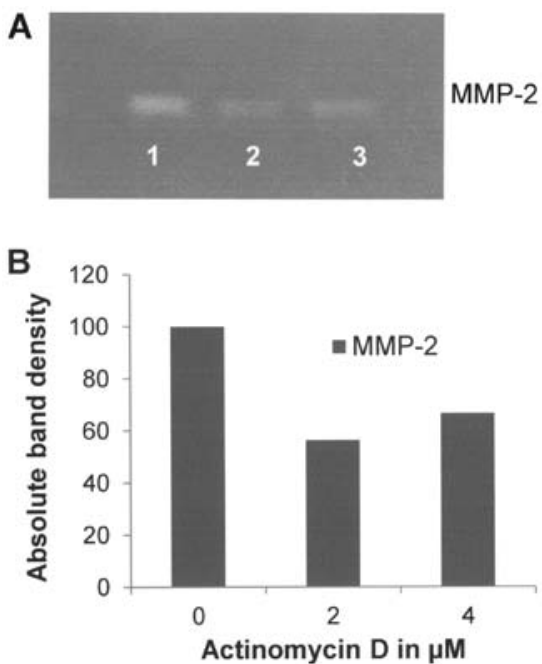

Figure 6. Effect of actinomycin-D on MMP-2 and MMP-9 secretion of normal FA-A:PD20 cells. (A) Gelatinase zymograms of normal FA fibroblast cells and (B) densitometry analysis of MMP-2. Lane 1, control; lanes 2 and 3: 2 and $4 \mu \mathrm{M}$ of actinomycin-D, respectively. MMP, matrix metalloproteinase; FA, Fanconi anemia.

EGCG downregulated the expression of MMP-2 at and over $50 \mu \mathrm{M}$, with $83 \%$ block at $100 \mu \mathrm{M}\left(\mathrm{R}^{2}=0.4337\right)$ as shown in Fig. 7A and C. EGCG showed inhibition of PMA-induced $(100 \mathrm{ng} / \mathrm{ml})$ MMP-9 $\left(\mathrm{R}^{2}=0.6554\right)$ and of MMP-2 $\left(\mathrm{R}^{2}=0.7476\right)$ in a dose-dependent manner with virtual total block of both at $100 \mu \mathrm{M}$ as shown in Fig. 7B and D.

NM inhibited the secretion of MMP-2 by uninduced FA fibroblast cells in a dose-dependent manner, with a linear trend of $\mathrm{R}^{2}=0.8706$ (Fig. 8A and C). NM showed dose-dependent inhibition of MMP-2 and MMP-9 expression in PMA-treated cells with virtual total blockage of both at $500 \mu \mathrm{g} / \mathrm{ml}$ as shown in Fig. $8 \mathrm{~B}$ and $\mathrm{C}$, with linear trends $\mathrm{R}^{2}=0.8479$ and 0.8597 , respectively.
A

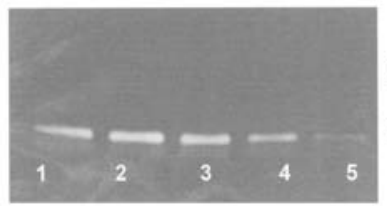

B
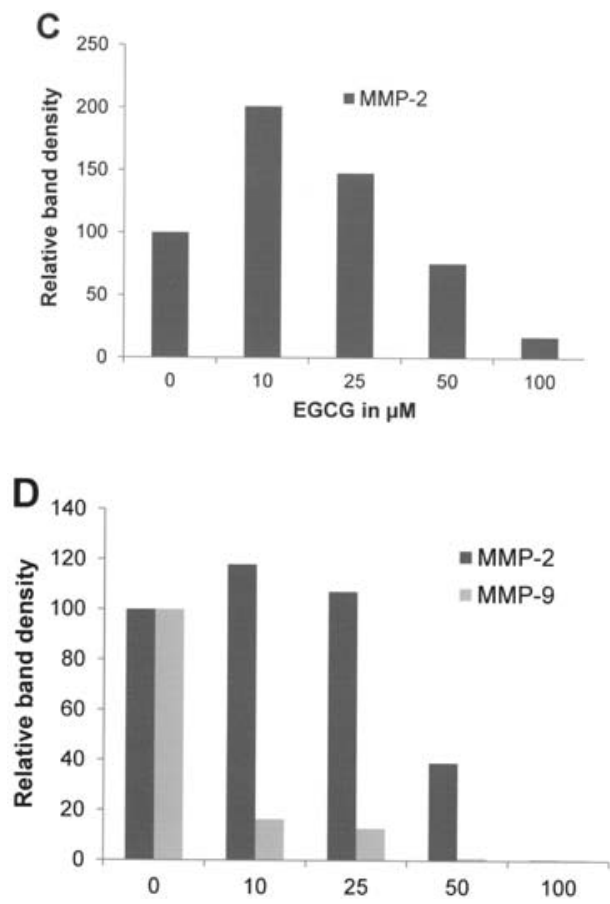

Figure 7. Effect of EGCG on MMP-2 and MMP-9 secretion of normal and PMA-treated (100 ng/ml) FA-A:PD20 cells. (A) Gelatinase zymograms of normal FA fibroblast cells and (B) PMA-treated FA fibroblast cells (C) Densitometry analysis of normal FA fibroblast cells and (D) PMA-treated FA fibroblast cells. Lane 1, markers; lane 2, control; lanes 2-5: 10, 25, 50 and $100 \mu \mathrm{M}$ of EGCG, respectively. EGCG, epigallocatechin gallate; MMP, matrix metalloproteinase; PMA, phorbol 12-myristate 13-acetate; FA, Fanconi anemia. 
A

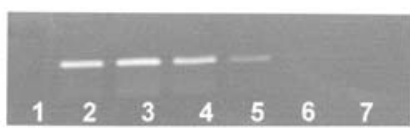

C

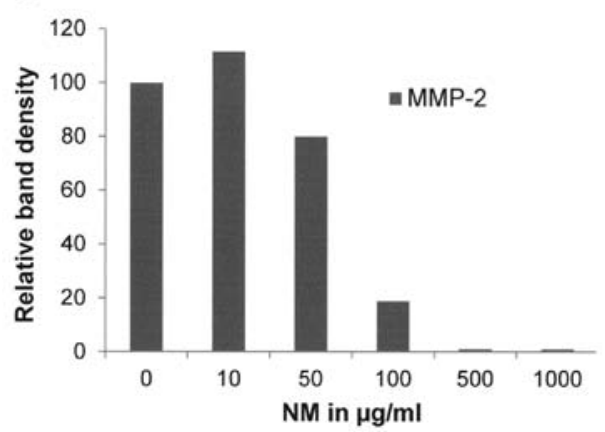

B

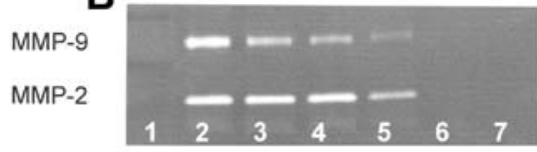

D

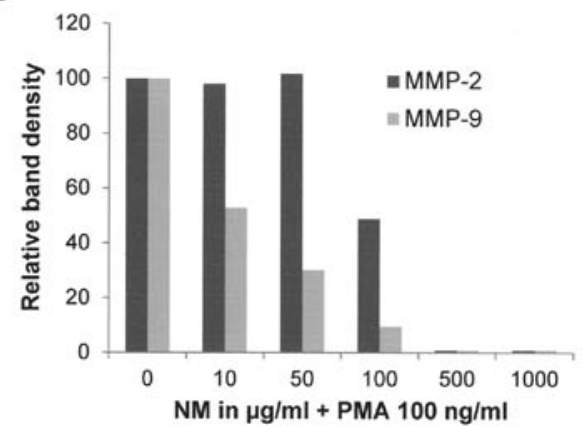

Figure 8. Effect of NM on MMP-2 and MMP-9 secretion of normal and PMA-treated (100 ng/ml) FA-A:PD20 cells. (A) Gelatinase zymograms of normal FA fibroblast cells and (B) PMA-treated FA fibroblast cells. (C) Densitometry analysis of normal FA fibroblast cells and (D) PMA-treated FA fibroblast cells. Lane 1, markers; lane 2, control; lanes 3-7: 10, 50, 100, 500 and 1,000 $\mu \mathrm{g} / \mathrm{ml}$ of NM, respectively. NM, nutrient mixture; MMP, matrix metalloproteinase; PMA, phorbol 12-myristate 13-acetate; FA, Fanconi anemia.

Retinoic acid inhibited FA fibroblast MMP-2 secretion by $93 \%$ at $50 \mu \mathrm{M}$ (data not shown).

\section{Discussion}

Elevated MMP levels correlate with tumor progression and metastasis, as documented in experimental and clinical studies $(5,6)$. Epanchintsev et al reported the overproduction of secretory factors in Fanconi anemia (FA), such as IL-6, IL-8, MMP-2 and MMP-9 and that overexpression of these secretory factors promoted the proliferation, migration and invasion of surrounding tumor cells (3). Thus, knowledge of MMP regulation is of importance for developing therapeutic strategies for FA. Extracellular factors, including cytokines, growth factors, inducers and inhibitors, have been implicated in the regulation of MMP expression in different types of tumor cells $(11,12)$.

In the present study, we compared MMP secretion patterns by cytokines, PMA and LPS in FA immortalized cell lines. In addition, we investigated the effect of inhibitors doxycycline, EGCG, nutrient mixture (NM) and others, such as dexamethasone, retinoic acid and agents that affect transcription and translation levels, such as actinomycin-D.

Among the inducers and cytokines, PMA treatment had a moderate stimulatory effect on MMP-2 and strong stimulation of MMP-9 secretion, TNF $\alpha$ had a negligible effect on MMP-2 and a significant stimulatory dose-dependent effect on MMP-9, IL-1 $\beta$ had slight stimulation on MMP- 2 at 1 and $10 \mathrm{ng} / \mathrm{ml}$ and significant stimulatory dose-dependent effects on MMP-9, and LPS showed a moderate stimulatory effect on MMP-2 secretion below $50 \mu \mathrm{M}$ and an inhibitory effect at 50 and $100 \mu \mathrm{M}$ and no effect on MMP-9.

Among the chemical inhibitors, doxycycline downregulated the secretion of FA fibroblast MMP-2 and MMP-9 in a dose-dependent manner, with virtual total blockage of MMP-2 at $100 \mu \mathrm{M}$ and of MMP-9 at $50 \mu \mathrm{M}$. In contrast, actinomycin$\mathrm{D}$ had a slight inhibitory effect on MMP-2 and a strong stimulatory effect on MMP-9 secretion. Dexamethasone had a potent inhibitory effect on MMP-2.

Among the natural inhibitors, EGCG downregulated the expression of MMP-2 and PMA induced MMP-9 expression in a dose-dependent manner with virtual total blockage of both at $100 \mu \mathrm{M}$. Similarly, NM showed dose-dependent inhibition of MMP-2 and MMP-9 expression in PMA-treated cells with virtual total blockage of both at $500 \mu \mathrm{g} / \mathrm{ml}$. Retinoic acid strongly inhibited FA fibroblast MMP-2 secretion.

NM, which contains micronutrients such as lysine, proline, ascorbic acid, and green tea extract, has demonstrated antitumor and anti-invasive potential in vivo and in vitro (13). The usage of combinations of micronutrients expands metabolic targets mediated by different pathways, and thus maximizes the biological impact with lower doses of components. For example, a previous comparative study on the effects of NM and its components such as green tea extract and EGCG on the inhibition of MMP-2 and MMP-9 secretion of different cancer cell lines with varying MMP secretion patterns, revealed the superior potency of NM over green tea extract and EGCG at equivalent doses (14).

We designed NM by selecting nutrients that act on critical physiological targets in cancer progression and metastasis, as documented in both clinical and experimental studies. Adequate levels of ascorbic acid, lysine and proline are essential for supporting proper synthesis and hydroxylation of collagen fibers to optimize ECM structure. In addition, lysine contributes to ECM stability as a natural inhibitor of plasmin-induced proteolysis $(15,16)$. Manganese and copper also contribute to collagen formation. Green tea extract has been shown to be potent in modulating cancer cell growth, metastasis, angiogenesis and other aspects of cancer progression (17-21). $N$-acetyl cysteine and selenium have been documented to suppress tumor cell MMP-9 and invasive activities, in addition to migration of endothelial cells through the ECM (22-24). Ascorbic acid has been documented to modulate cancer cell and tumor growth as well as to prevent 
metastasis (25-30) and low levels of ascorbic acid are found in cancer patients $(31,32)$. Low levels of arginine limit NO production, an inducer of apoptosis (33).

In conclusion, our results demonstrated that cytokines, mitogens and inhibitors modulated FA fibroblast MMP-2 and MMP-9 secretion, suggesting the clinical use of MMP inhibitors, particularly potent and non-toxic ones such as NM and its component EGCG in the management of FA cancers.

\section{Acknowledgements}

The present study was funded by Dr. Rath Health Foundation (Santa Clara, CA, USA), a non-profit organization.

\section{References}

1. Donahue SL and Campbell C: A DNA double strand break repair defect in Fanconi anemia fibroblasts. J Biol Chem 277: 46243-46247, 2002.

2. Donahue SL, Lundberg R, Saplis R and Campbell C: Deficient regulation of DNA double-strand break repair in Fanconi anemia fibroblasts. J Biol Chem 278: 29487-29495, 2003.

3. Epanchintsev A, Shyamsunder P, Verma RS and Lyakhovich A: IL-6, IL-8, MMP-2, MMP-9 are overexpressed in Fanconi anemia cells through a NF- $\kappa \mathrm{B} / \mathrm{TNF}-\alpha$ dependent mechanism. Mol Carcinog 54: 1686-1699, 2015.

4. Ibáñez A, Río P, Casado JA, Bueren JA, Fernández-Luna JL and Pipaón C: Elevated levels of IL-1 $\beta$ in Fanconi anaemia group A patients due to a constitutively active phosphoinositide 3-kinaseAkt pathway are capable of promoting tumour cell proliferation. Biochem J 422: 161-170, 2009.

5. Liotta LA, Tryggvason K, Garbisa S, Hart I, Foltz CM and Shafie S: Metastatic potential correlates with enzymatic degradation of basement membrane collagen. Nature 284: 67-68, 1980.

6. Stetler-Stevenson WG: The role of matrix metalloproteinases in tumor invasion, metastasis, and angiogenesis. Surg Oncol Clin N Am 10: 383-392, 2001.

7. Stetler-Stevenson WG: Type IV collagenases in tumor invasion and metastasis. Cancer Metastasis Rev 9: 289-303, 1990.

8. Sato T, Sakai T, Noguchi Y, Takita M, Hirakawa S and Ito A: Tumor-stromal cell contact promotes invasion of human uterine cervical carcinoma cells by augmenting the expression and activation of stromal matrix metalloproteinases. Gynecol Oncol 92: 47-56, 2004.

9. Pyke C, Kristensen P, Ralfkiaer E, Grøndahl-Hansen J, Eriksen J, Blasi F and Danø K: Urokinase-type plasminogen activator is expressed in stromal cells and its receptor in cancer cells at invasive foci in human colon adenocarcinomas. Am J Pathol 138: 1059-1067, 1991.

10. Vincenti MP, White LA, Schroen DJ, Benbow U and Brinckerhoff CE.: Regulating expression of the gene for matrix metalloproteinase-1 (collagenase): Mechanisms that control enzyme activity, transcription and mRNA stability. Crit Rev Eukaryot Gene Expr 6: 391-411, 1996.

11. Ray JM and Stetler-Stevenson WG: The role of matrix metalloproteases and their inhibitors in tumour invasion, metastasis and angiogenesis. Eur Respir J 7: 2062-2072, 1994.

12. Apodaca G, Rutka JT, Bouhana K, Berens ME, Giblin JR, Rosenblum ML, McKerrow JH and Banda MJ: Expression of metalloproteinases and metalloproteinase inhibitors by fetal astrocytes and glioma cells. Cancer Res 50: 2322-2329, 1990

13. Niedzwiecki A, Roomi MW, Kalinovsky T and Rath M: Micronutrient synergy - a new tool in effective control of metastasis and other key mechanisms of cancer. Cancer Metastasis Rev 29: 529-542, 2010.

14. Roomi MW, Monterrey JC, Kalinovsky T, Rath M and Niedzwiecki A: Comparative effects of EGCG, green tea and a nutrient mixture on the patterns of MMP-2 and MMP-9 expression in cancer cell lines. Oncol Rep 24: 747-757, 2010.
15. Rath M and Pauling L: Plasmin-induced proteolysis and the role of apoprotein(a), lysine and synthetic analogs. Orthomolecular Med 7: 17-23, 1992.

16. Sun Z, Chen YH, Wang P, Zhang J, Gurewich V, Zhang P and Liu JN: The blockage of the high-affinity lysine binding sites of plasminogen by EACA significantly inhibits prourokinase-induced plasminogen activation. Biochim Biophys Acta 1596: 182-192, 2002.

17. Valcic S, Timmermann BN, Alberts DS, Wächter GA, Krutzsch M, Wymer J and Guillén JM: Inhibitory effect of six green tea catechins and caffeine on the growth of four selected human tumor cell lines. Anticancer Drugs 7: 461-468, 1996.

18. Mukhtar H and Ahmad N: Tea polyphenols: Prevention of cancer and optimizing health. Am J Clin Nutr 71 (Suppl 6): 1698S-1704S, 2000.

19. Yang GY, Liao J, Kim K, Yurkow EJ and Yang CS: Inhibition of growth and induction of apoptosis in human cancer cell lines by tea polyphenols. Carcinogenesis 19: 611-616, 1998.

20. Taniguchi S, Fujiki H, Kobayashi H, Go H, Miyado K, Sadano H and Shimokawa R: Effect of (-)-epigallocatechin gallate, the main constituent of green tea, on lung metastasis with mouse B16 melanoma cell lines. Cancer Lett 65: 51-54, 1992.

21. Hara Y:Greentea:HealthBenefits and Applications.MarcelDekker, New York, Basel, 2001. http://dx.doi.org/10.1201/9780203907993.

22. Kawakami S, Kageyama Y, Fujii Y, Kihara K and Oshima H: Inhibitory effect of $\mathrm{N}$-acetylcysteine on invasion and MMP-9 production of T24 human bladder cancer cells. Anticancer Res 21: 213-219, 2001

23. Morini M, Cai T, Aluigi mg, Noonan DM, Masiello L, De Flora S, D'Agostini F, Albini A and Fassina G: The role of the thiol $\mathrm{N}$-acetylcysteine in the prevention of tumor invasion and angiogenesis. Int J Biol markers 14: 268-271, 1999.

24. Yoon SO, Kim MM and Chung AS: Inhibitory effect of selenite on invasion of HT1080 tumor cells. J Biol Chem 276: 20085-20092, 2001.

25. Cha J, Roomi MW, Ivanov V, Kalinovsky T, Niedzwiecki A and Rath M: Ascorbate supplementation inhibits growth and metastasis of B16FO melanoma and 4T1 breast cancer cells in vitamin C-deficient mice. Int J Oncol 42: 55-64, 2013.

26. Naidu KA, Karl RC, Naidu KA and Coppola D: Antiproliferative and proapoptotic effect of ascorbyl stearate in human pancreatic cancer cells: Association with decreased expression of insulin-like growth factor 1 receptor. Dig Dis Sci 48: 230-237, 2003.

27. Anthony HM and Schorah CJ: Severe hypovitaminosis C in lung-cancer patients: The utilization of vitamin $\mathrm{C}$ in surgical repair and lymphocyte-related host resistance. Br J Cancer 46: 354-367, 1982.

28. Maramag C, Menon M, Balaji KC, Reddy PG and Laxmanan S: Effect of vitamin $C$ on prostate cancer cells in vitro: Effect on cell number, viability, and DNA synthesis. Prostate 32: 188-195, 1997.

29. Koh WS, Lee SJ, Lee H, Park C, Park MH, Kim WS, Yoon SS, Park K, Hong SI, Chung MH, et al: Differential effects and transport kinetics of ascorbate derivatives in leukemic cell lines. Anticancer Res 18: 2487-2493, 1998.

30. Chen Q, Espey mg, Krishna MC, Mitchell JB, Corpe CP, Buettner GR, Shacter E and Levine M: Pharmacologic ascorbic acid concentrations selectively kill cancer cells: Action as a pro-drug to deliver hydrogen peroxide to tissues. Proc Natl Acad Sci USA 102: 13604-13609, 2005.

31. Núñez Martín C and Ortiz de Apodaca y Ruiz A: Ascorbic acid in the plasma and blood cells of women with breast cancer. The effect of the consumption of food with an elevated content of this vitamin. Nutr Hosp 10: 368-372, 1995 (In Spanish).

32. Kurbacher CM, Wagner U, Kolster B, Andreotti PE, Krebs D and Bruckner HW: Ascorbic acid (vitamin C) improves the antineoplastic activity of doxorubicin, cisplatin, and paclitaxel in human breast carcinoma cells in vitro. Cancer Lett 103: 183-189, 1996.

33. Cooke JP and Dzau VJ: Nitric oxide synthase: Role in the genesis of vascular disease. Annu Rev Med 48: 489-509, 1997. 